\title{
Obesity-Driven Gut Microbiota Inflammatory Pathways to Metabolic Syndrome
}

\author{
Luiz H. A. Cavalcante-Silva ${ }^{1}$, José G. F. M. Galvão ${ }^{1}$, Juliane Santos de França da Silva ${ }^{2}$, \\ José M. de Sales-Neto ${ }^{3}$ and Sandra Rodrigues-Mascarenhas ${ }^{1,2,3 *}$ \\ ${ }^{1}$ Programa Multicêntrico de Pós-graduação em Ciências Fisiológicas, Laboratório de Imunofarmacologia, Centro de \\ Biotecnologia, Universidade Federal da Paraíba, João Pessoa, Brasil, ${ }^{2}$ Programa de Pós-Graduação em Produtos Naturais \\ e Sintéticos Bioativos, Laboratório de Imunofarmacologia, Centro de Ciências da Saúde, Universidade Federal da Paraíba, \\ João Pessoa, Brasil, ${ }^{3}$ Programa de Pós-Graduação em Biotecnologia, Laboratório de Imunofarmacologia, Centro de \\ Biotecnologia, Universidade Federal da Paraíba, João Pessoa, Brasil
}

The intimate interplay between immune system, metabolism, and gut microbiota plays an important role in controlling metabolic homeostasis and possible obesity development. Obesity involves impairment of immune response affecting both innate and adaptive immunity. The main factors involved in the relationship of obesity with inflammation have not been completely elucidated. On the other hand, gut microbiota, via innate immune receptors, has emerged as one of the key factors regulating events triggering acute inflammation associated with obesity and metabolic syndrome. Inflammatory disorders

Edited by:

Ovidiu Constantin Baltatu, Camilo Castelo Branco University,

Brazil

Reviewed by:

Giovanni Solinas,

University of Gothenburg, Sweden Ilana Kolodkin-Gal,

Weizmann Institute of Science, Israel

*Correspondence:

Sandra Rodrigues-Mascarenhas sandra@cbiotec.ufpb.br

Specialty section:

This article was submitted to Integrative Physiology, a section of the journal Frontiers in Physiology

Received: 20 June 2015 Accepted: 03 November 2015 Published: 19 November 2015

Citation:

Cavalcante-Silva LHA, Galvão JGFM, Silva JSF, Sales-Neto JM and Rodrigues-Mascarenhas S (2015)

Obesity-Driven Gut Microbiota Inflammatory Pathways to Metabolic Syndrome. Front. Physiol. 6:341. doi: 10.3389/fphys.2015.00341 lead to several signaling transduction pathways activation, inflammatory cytokine, chemokine production and cell migration, which in turn cause metabolic dysfunction. Inflamed adipose tissue, with increased macrophages infiltration, is associated with impaired preadipocyte development and differentiation to mature adipose cells, leading to ectopic lipid accumulation and insulin resistance. This review focuses on the relationship between obesity and inflammation, which is essential to understand the pathological mechanisms governing metabolic syndrome.

Keywords: adipose tissue, cytokines, gut microbiota, immune system, toll-like receptors

\section{GUT MICROBIOTA ROLE IN OBESITY}

Obesity has increased alarmingly worldwide, promoting mortality and morbidity (Mitchell and Shaw, 2015). Overweight and obesity are commonly associated with accumulated abdominal visceral fat and can be related to psycho-sociological behavioral disorders (Burdette and Hillb, 2008; Jauch-Chara and Oltmanns, 2014). Fat gain and adipose tissue inflammation, resulted from excessive caloric intake and reduced energy expenditure, lead to positive energy balance and can contribute to metabolic syndrome (Trayhurn, 2005; Emanuela et al., 2012; DeMarco et al., 2014). Besides, chronic stress and gut microbiota deregulation can affect obesity development (McGill, 2014).

Human microbiota, made up of bacteria, archaeas, viruses and unicellular eukaryotes, represents more than $10^{14}$ microbial cells/humam, which live peacefully in our body (Sekirov et al., 2010). These microbes are found in our skin, genitourinary, respiratory and gastrointestinal tracts. Gut microbiota represents over than $7 \times 10^{13}$ microbial cells/human, but its composition can be altered throughout life, including changes in gene expression (Walsh et al., 2014). 
There are over 50 bacterial phyla, but the human gut microbiota is dominated mostly by the Bacteroidetes and the Firmicutes (Schloss and Handelsman, 2004; Sekirov et al., 2010). Gut specific microbial phyla, species and strains of humans and other animals are related to gene expression alterations observed in obesity (Ley et al., 2005; Turnbaugh et al., 2008; Fujimura et al., 2010; Clarke et al., 2012; Cotillard et al., 2013; de Theije et al., 2014). It has been demonstrated that obesity is associated with reduced bacterial diversity and modified representation of bacterial genes and metabolic pathways (Turnbaugh et al., 2009). Furthermore, Turnbaugh et al. (2006) provide evidences that gut microbiota in obese mice have an increased ability for energy harvest from the diet. In this work, colonization of germ-free mice with caecal microbiota harvested from obese donors results in a significant total body fat gain.

Probiotics (e.g., many bacterial strains of the Lactobacillus and Bifidobacterium genera), when administered in adequate amounts, induces health-beneficial effects, representing a novel anti-obesity mechanism (Raoult, 2009; Aronsson et al., 2010; Kadook et al., 2010). Studies demonstrated that Lactobacillus treatment reduces fat accumulation and pro-inflammatory cytokines in adipose tissue (Park et al., 2013; Yoo et al., 2013; Miyoshi et al., 2014; Ukibe et al., 2015). Lactobacillus strain (L. plantarum) anti-inflammatory effect was also observed in intestinal inflammation rat model, mostly by NF-кB (nuclear factor kappa-light-chain-enhancer of activated B cells) inhibition (Štofilová et al., 2015). Similar results were also observed in endotoxin- and metabolic-related inflammatory process in rats (Vilahur et al., 2015). However, in diabetic and non-diabetic individuals, oral supplementation with another Lactobacillus strain (i.e., L. acidophilus) did not affect systemic inflammatory response (Andreasen et al., 2010). These opposite results could be related to differences in Lactobacillus strains or even to different experimental models.

Lactobacillus effect on fat storage may involve upregulation of circulating lipoprotein lipase inhibitor, angiopoietin-like 4 protein (ANGPTL4), which controls triglyceride deposition into adipocytes (Aronsson et al., 2010). In addition, probiotics treatment can modulate gut flora composition, which in turn enhance metabolic functions to prevent overweight and obesity (Park et al., 2013; Yadav et al., 2013). Moreover, obese mice antibiotics treatment is also capable to reduce adiposity and adipose tissue inflammation, which reinforce the benefits of gut microbiota regulation (Tremaroli and Bäckhed, 2012).

Gastrointestinal microbiota also interferes with carbohydrate, lipid and amino acid metabolism (Hooper et al., 2002), complementing our own human metabolic apparatus (Bäckhed et al., 2004, 2007; Cani and Delzenne, 2009; Rabot et al., 2010). Thus, human gut microbiota can regulate many metabolic pathways, including bile acids biotransformation, which involves deconjugation, dehydroxylation, and reconjugation reactions (Ridlon et al., 2014). Gut microbiota components, such as bacterial bile salt hydrolases and bacterial $7 \alpha$-dehydroxylase, can control these reactions and, thus, maintain bile acids pool size and composition (Ridlon et al., 2006). It has been demonstrated that bile acids have both direct antimicrobial effects on gut microbes and indirect effects through FXR (farnesoid X receptor)-induced antimicrobial peptides (Inagaki et al., 2006). This antimicrobial effect promoted by bile acids prevent mucosal injury in the small intestine and other injuries caused by excessive bacterial proliferation (Hofmann and Eckmann, 2006; Merritt and Donaldson, 2009). It was also described that reduced bile acid levels in the gut are associated with bacterial overgrowth and inflammation. However, some bacteria, such as Alistipes, Bilophila, and Bacteroides, are bile acids tolerant, which could lead to other symbiotic microbes suppression (David et al., 2014).

Bile acids can also regulate adiposity and glucose homeostasis. Studies demonstrated that nuclear receptor FXR deficiency leads to mass adipose tissue reduced levels (Cariou et al., 2006; Prawitt et al., 2011). On the other hand, FXR absence has different effects on glucose homeostasis in lean and obese mice. FXR ${ }^{-/-}$lean mice presents impaired glucose tolerance and insulin resistance (Cariou et al., 2006; Ma et al., 2006), while obese mice (murine models of genetic and diet-induced obesity) presents glucose homeostasis improvement (Prawitt et al., 2011). This difference can be explained by bile acids action in other receptors, such as TGR5 (also known as G protein bile acid receptor-1), since Thomas et al. (2009) showed that TGR5 activation results in the maintenance of glucose homeostasis and insulin sensitivity in obese mice.

Furthermore, gut microbiota plays a physiological role in host immune system development [e.g., gut-associated lymphoid tissue (GALT) development] (Bäckhed et al., 2005; Willing et al., 2010; Guinane and Cotter, 2013) and immune tolerance modulation (Bailey et al., 2005; Vael and Desager, 2009; Martin et al., 2010; Belkaid and Hand, 2014). In addition, gut microbiota modulates other important intestinal functions such as angiogenesis and epithelium function (Hooper et al., 2001). Epithelial (e.g., enterocytes and goblet cells) and endocrine cells provide an interplay between the host and its own gut microbiota via receptors such as toll-like receptors (TLRs; Lotz et al., 2003; Kelly et al., 2004; Hornef and Bogdan, 2005; Shibolet and Podolsky, 2007; Wells et al., 2011; Pott and Hornef, 2012). After TLR activation, pro-inflammatory molecules can be produced in the gut microbiota and impair host metabolism, which in turn can further cause adipose inflammation and obesity (Sanz and Moya-Pérez, 2014).

Additionally, gut homeostasis is related to other innate immune receptors, such as nucleotide-binding oligomerization domain (NOD) like receptors (NLR; Zambetti and Mortellaro, 2014). This family of cytosolic receptors includes NOD1/2 and NLRPs (NLR family, pyrin-domain-containing proteins). After activation, NLRP forms signaling complexes called inflammasomes, which generate active forms of the inflammatory cytokine IL-1 $\beta$ and IL-18. Some different inflammasome subtypes have been described such as NLRP1, NLRP3, NLRP6, NLRC4, AIM2 (Latz et al., 2013). Studies have demonstrated that NLRC4 inflammasome is involved in mucosal protection against infections (Sellin et al., 2014; Nordlander et al., 2014), while NLRP6 and NLRP3 are associated with gut microbiota homeostasis (Elinav et al., 2011; Hirota et al., 2011; Wlodarska et al., 2014). Inflammasomes and gut homeostasis interaction is substantially detailed by Sellin et al. (2015) and Zambetti and Mortellaro (2014). 


\section{INTERPLAY BETWEEN INFLAMMATION AND OBESITY}

Inflammation is a tightly controlled physiological process that is orchestrated by immune system (Ashley et al., 2012), but is also regulated by other systems, such as endocrine (de Vasconcelos et al., 2011; Leite et al., 2015; Ren et al., 2015) and nervous system (Martelli et al., 2014; Bassi et al., 2015). Despite the protective body response represented by inflammation, deregulated, or excessive immune response can lead to several chronic diseases such as hypertension (Mirhafez et al., 2014), Alzheimer (Takeda et al., 2014), and obesity (Khan et al., 2014). The classical acute inflammatory process includes five cardinal signals: redness, heat, swelling, pain, and, eventually, loss of function (Medzhitov, 2010). These macroscopic signals are reflex of vascular (e.g., vascular permeability) and cellular (e.g., leukocytes migration) alterations during inflammation (Medzhitov, 2008). However, inflammatory response in obesity has some particular features (Gregor and Hotamisligil, 2011). Obesity involves immune response impairment affecting both innate and adaptive immunity. However, the mechanisms involved in the relationship between obesity and inflammation have not been completely elucidated (Sanz and Moya-Pérez, 2014).

Obesity is related to inflamed adipose tissue and increased local cell infiltration (Gregor and Hotamisligil, 2011). Different cell types contribute to adipose tissue inflammation, among these cells monocytes/macrophages play a critical role in this process (Cinti et al., 2005; Subramanian and Ferrante, 2009; Ferrante, 2013). Yoshimura et al. (2015) demonstrated that obese young adults have increased number of leukocytes, mostly monocytes, when compared with non-obese individuals. Also, elevated monocytes level is positively correlated with visceral subcutaneous fat as well as with body fat mass. Peripheral blood of obese women presents an elevated inflammatory monocytes amount (Ziegler-Heitbrock, 2007; Krinninger et al., 2014). In addition, Poitou et al. (2011) also demonstrated that inflammatory monocytes are increased in obese individuals and fat body loss is associated with significant decrease of these cells.

Once within tissues, monocytes differentiate in M1 or M2 polarized macrophages (Dalmas et al., 2011). The first type is classified in pro-inflammatory cell which expresses inducible nitric oxide synthase and pro-inflammatory cytokines (e.g., IL6 and TNF- $\alpha$ ), while M2 macrophages express arginase (Arg1) and the anti-inflammatory cytokine IL-10. In lean individuals, M2 macrophage predominates in adipose tissue unlike in obese individuals; wherein M1 macrophages are mostly present (Kraakman et al., 2014). Macrophages of high-fat diet fed mice display autophagy impairment, a cytoprotective response to different stimulus, which leads to M1 polarization (Liu et al., 2015).

In obese individuals, monocytes up-regulate chemokine receptor type 2 (CCR2) and thus they migrate toward adipose tissue. Despite the natural ligand of this receptor, the chemokine CCL2 (also as known as MCP-1), plays an important role in adipose tissue macrophage recruitment (Kanda et al., 2006), other studies demonstrated that CCL2 is not critical for macrophage infiltration into adipose tissue (Inouye et al., 2007; Kirk et al., 2008). These findings can be related to macrophage recruitment toward adipose tissue by other chemokine, such as CXCL12 and CXCL14, as demonstrated by Kim et al. (2014) and Nara et al. (2007), respectively. Furthermore, the chemokine CCL5 (also as known as RANTES) and its receptors CCR5 are also important in this macrophage migration process (Keophiphath et al., 2010; Kitade et al., 2012).

Additionally, CCR2 modulates other parameters than macrophage recruitments. High-fat diet fed mice with genetic CCR2 deficiency present food intake reduction and lower obesity development (Weisberg et al., 2006). In addition, obese CCR2 ${ }^{-/-}$mice have an increased adipose tissue eosinophil number and high levels of IL-4 and IL-13, cytokines which lead to M2 macrophage polarization (Bolus et al., 2015).

Not only migration, but also macrophage proliferation contributes to adipose tissue inflammation. Amano et al. (2014) showed that obese mice increased macrophage proliferation, especially in visceral adipose tissue. Moreover, they showed that CCL2 stimulates adipose tissue macrophage proliferation.

Adipose tissue macrophages are source of inflammatory cytokines in obese individuals. Between these cytokines, IL6 displays pleiotropic role in metabolism and obesity. Sárvári et al. (2015) demonstrated that macrophages engulf portions of adipocytes in vitro leading to NF- $\mathrm{KB}$ activation and IL6 secretion. In addition, Kraakman et al. (2015) related proinflammatory action to IL-6 trans-signaling, a process where IL-6 binds a soluble receptor to trigger inflammation. In this work, they demonstrated that this IL-6 signaling induces macrophage recruitment to adipose tissue.

IL-6 can also induce C reactive protein (CRP) liver production, which is associated to complement activation, phagocytosis and cytokines production (Deban et al., 2009; Du Clos, 2013). In obese individuals, CRP is elevated, demonstrating a state of active immune response and inflammation in these subjects (Shaharyar et al., 2015; Yoshimura et al., 2015). On the other hand, Ma et al. (2015), using a different model, showed that sustained IL-6 gene expression in obese mice reduces body weight loss, fatty liver and insulin resistance. Additionally, it was evidenced that IL-6 supports M2 polarization, an anti-inflammatory cell, by sensitizing macrophages to IL-4 (Mauer et al., 2014). Despite its variable effects, these findings demonstrate IL- 6 critical role of in obese individuals.

Although macrophages infiltration is considered a hallmark of adipose tissue inflammation, other cells of the immune system display a fundamental role (Sell et al., 2012). In fact, some studies demonstrated that neutrophil migration into adipose tissue, as well as in classical acute inflammation, occurs after 3 days of high-fat diet in mice (Elgazar-Carmon et al., 2008; Talukdar et al., 2012). In addition, Xu et al. (2015) demonstrated an increased peripheral blood neutrophil percentage in obese young male.

Several types of lymphocytes interact with other cells in adipose tissue environment to enhance or decrease inflammatory response. Interactions between macrophages and $\mathrm{CD} 4^{+} \mathrm{T}$ cell via $\mathrm{MHC}$ class II is required for adipose tissue inflammation and for obesity-induced insulin resistance (Cho et al., 2014). $\mathrm{CD}^{+} \mathrm{T}$ cell could polarize to different subtypes of lymphocytes, 
TABLE 1 | Role of lymphoid origin cells in obesity-related inflammation.

\begin{tabular}{|c|c|}
\hline $\begin{array}{l}\text { Lymphoid subsets } \\
\text { cells }\end{array}$ & Role in obesity \\
\hline Th17 & $\begin{array}{l}\text { Increased in obese individuals (Winer et al., 2009). } \\
\text { IL-17A, a Th17 key cytokine, up-regulates IL-6, IL-8, and } \\
\text { PGE2 levels in adipocytes (Shin et al., 2009). }\end{array}$ \\
\hline Th22 & $\begin{array}{l}\text { Increased in obese individuals (Zhao et al., 2014). } \\
\text { Unclear role. }\end{array}$ \\
\hline NK cell & $\begin{array}{l}\text { Contributes to M1 macrophage polarization (Wensveen } \\
\text { et al., 2015). }\end{array}$ \\
\hline iNKT & $\begin{array}{l}\text { Induce M2 macrophage polarization and control Treg } \\
\text { proliferation (Lynch et al., 2015). }\end{array}$ \\
\hline $\begin{array}{l}\text { ILC2s (group } 2 \text { innate } \\
\text { lymphoid cells) }\end{array}$ & $\begin{array}{l}\text { Control obesity development by inducing caloric } \\
\text { expenditure (Brestoff et al., 2014). }\end{array}$ \\
\hline
\end{tabular}

namely Th1, Th2, Th17, regulatory $\mathrm{T}$ (Treg) cells, and other types of cells (Luckheeram et al., 2012). Despite all these subtypes of cells are related to obesity and metabolic syndrome, proinflammatory Th1 and Th17 predominate over Treg and Th2 during adipose tissue inflammation (Sell et al., 2012; McLaughlin et al., 2014).

High-fat diet fed mice present Th1 polarized and IFN- $\gamma$ production predominance, which occurs after macrophage recruitment (Strissel et al., 2010). IFN- $\gamma$ expression displays a regulatory role in adipose tissue inflammation, since its absence reduces TNF- $\alpha$ and CCL- 2 mRNA expression and macrophage adipose tissue accumulation (Rocha et al., 2008). Interestingly, T-box transcription factor (T-bet) absence, a key factor to development of Th1 cell, leads to obesity possibly by IL-6 upregulation (Kim et al., 2013). In Table 1, we summarize other types of lymphoid cells involved in obesity-related inflammation.

Immune cells need to sense foreign structures to develop an immunological response. Particularly, innate immune cells use pattern recognition receptors (PRR) to recognize specific pathogen or damaged molecules (Janeway and Medzhitov, 2002). Between these receptors, toll-like receptors are structurally and functionally well-defined (Kawai and Akira, 2010), and are related to obesity.

\section{TOLL-LIKE RECEPTORS (TLR) AND OBESITY}

TLRs (toll-like receptors) can recognize pathogen-associated molecular patterns (PAMPs) of microorganisms, which are not conserved in eukaryotes. This recognition triggers immune system activation, setting up innate immune response (Kawai and Akira, 2010). These receptors were initially identified in the fruit fly Drosophila melanogaster, first being associated with its embryonic development. Later on, its role on pathogens detection and immune response was described (Lemaitre et al., 1996; Williams et al., 1997). Janeway and his collaborators identified the first toll homolog in humans, the TLR4 (Medzhitov et al., 1997). In mammals, there are 12 members from TLRs family, but only TLR1-TLR10 function is known (Akira et al., 2006).
TLRs location is important to grant the access to the ligand. The majority of plasma membrane TLRs recognizes microbial membranes components, such as proteins, lipoproteins and lipids; while intracellular TLRs are able to recognize nucleic acids of microorganism (Werling and Jungi, 2003). TLRs can recognize a broad variety of PAMPs derived from many classes of microorganisms such as parasites, fungi, viruses and bacteria (Medzhitov, 2007). These PAMPs include many molecules including $\beta$-glucan, found on fungus, both viral RNA and DNA, and also a huge quantity of elements derived from bacteria (e.g., lipopeptides, peptidoglycan, lipoteichoic acid, and lipopolysaccharide (LPS; Aderem and Ulevitch, 2000).

Despite the fact that TLRs recognize a variety of PAMPs, each TLR can only recognize a limited group of patterns and, therefore, has a determined specificity for their ligands (Beutler, 2003). TLR4 is the LPS receptor (Poltorak et al., 1998a,b). TLR2 was found to recognize bacterial peptidoglycan and lipopeptide (Takeuchi et al., 1999). TLR5 is able to recognize flagellin, a protein derived from bacterial flagella (Hayashi et al., 2001). TRL3 is associated to the identification of double-stranded RNA molecules (Alexopoulou et al., 2001). TLR7 can recognize RNA molecules, especially small interfering RNAs (Hornung et al., 2005). TLR8 is similar to TLR7 and recognize viral ssRNA. Finally, TLR9 is associated with the recognition of non-methylated bacterial DNA (Hemmi et al., 2000). Together, all these receptors are able to recognize a broad variety of microorganisms and promote activation of the NF- $\kappa \mathrm{B}$, which is responsible for synthesis of inflammatory mediators (Lee et al., 2012).

TLRs are specially expressed in hematopoietic cells, including immune system cells. However, its expression was already confirmed in other kind of cells such as adipocytes (Kanczkowski et al., 2008). Therefore, these receptors can act promoting interplay between the innate immune system and metabolism (Fresno et al., 2011). Studies conducted on the role of TLRs on adipose tissue suggest that all subtypes of TLRs can be found in this tissue. (Hwa et al., 2006; Pietsch et al., 2006; Poulain-Godefroy and Froguel, 2007; Vitseva et al., 2008). Nevertheless, initially only TLR2 and TLR4 were functional in human adipocytes (Bès-Houtmann et al., 2007), but lately TLR5 activation was evidenced (Pekkala et al., 2015). It was described that TLR2, TLR4, or TLR5 deficiency have a major role on obesity development (Fresno et al., 2011).

It was described that TLR2 activation can be triggered by saturated fatty acids (SFAs; Lee et al., 2001, 2003). During endotoxemia, TLR2 is also activated by bacterial peptidoglycan from the intestines (Cani et al., 2008). Moreover, TLR2 absence decreases expression of inflammatory mediators and macrophages infiltration in white adipose tissue (WAT). Also, other studies demonstrated that TLR2 reduced levels protects against obesity and inflammation (Himes and Smith, 2010; Davis et al., 2011). Together, these data reveal a certain importance regarding TLR2 role in obesity. In addition, the role played by TLR5 in obesity is not well-established. It was recently found that TLR5 signaling in adipose tissue could corroborate to obesity, inflammation and metabolic alterations. Additionally, it was reported that TLR5 activation leads to ERK1/2 (extracellular 
signal-regulated kinase) phosphorylation and adipocytes insulin signaling inhibition (Pekkala et al., 2015).

Both obesity and metabolic syndrome are characterized by inflammatory responses, triggered by adipose tissue disruption mediated TLR signaling (Pekkala et al., 2015). After activation, individual TLRs recruit TIR (Toll/IL-1 receptor) domaincontaining adaptors members such as MyD88 (Myeloid differentiation primary response gene 88 ), TRIF (TIR-domaincontaining adapter-inducing interferon- $\beta$ ), TIRAP/MAL (Toll-interleukin 1 receptor domain containing adaptor protein/ MyD88 adapter-like) or TRAM (TRIF-related adaptor molecule). However, MyD88 is used by all TLRs to activate NF-кB and MAPKs (mitogen-activated protein kinases) for the induction of inflammatory cytokine genes (Kawasaki and Kawai, 2014).

\section{TLR4 AND CELL SIGNALING PROTEINS: TARGETS TO OBESITY AND ITS COMPLICATIONS}

Obese patients express high levels of TLR4 (Reyna et al., 2008). TLR4 activation, which occurs in obesity, can be activated by gut microbial patterns, such as LPS, to promote inflammatory mediators production (Kim et al, 2012). In addition, TLR4 can also mediate the pro-inflammatory effect of SFAs, often found at high levels in plasma of obese individuals (Lee et al., 2001; Shi et al., 2006; Dasu and Jialal, 2010). Many studies demonstrated that decreased TLR4 expression protects from obesity development, adipose tissue inflammation and insulin resistance (Shi et al., 2006; Suganami et al., 2007; Tsukumo et al., 2007; Davis et al., 2008; de Mello et al., 2008). A similar effect was observed using anti-TLR4 antibodies (Milanski et al., 2009). In TLR4 deficient mice, adipose tissue inflammation reduction could be explained by M2 macrophage polarization (Orr et al., 2012).

Studies suggest that obesity TLR4 signaling essentially depends on MyD88 expression and up-regulated NF- $\kappa \mathrm{B}$ activity, with IL-6 and TNF- $\alpha$ pro-inflammatory cytokines increased expression (Fresno et al., 2011). Despite this classical signaling pathway, new insights about TLR4 signaling are emerging. In fact, Luo et al. (2014) demonstrated that small GTPase Rab8a and phosphatidylinositol 3-kinase $\gamma(\mathrm{PI} 3 \mathrm{~K} \gamma)$ act as regulators of cytokines production, decreasing pro-inflammatory cytokines and increasing anti-inflammatory cytokines. These effects are mediated by Akt/mTOR signaling. The protein kinase mTOR restrains the pro-inflammatory cytokines production by NF-кB inhibition, while the anti-inflammatory cytokine (i.e., IL-10) are enhanced by STAT3 activation (Weichhart et al., 2008). Thus, the TLR4 signaling can regulate the inflammatory response by modulating different transcriptions factors.

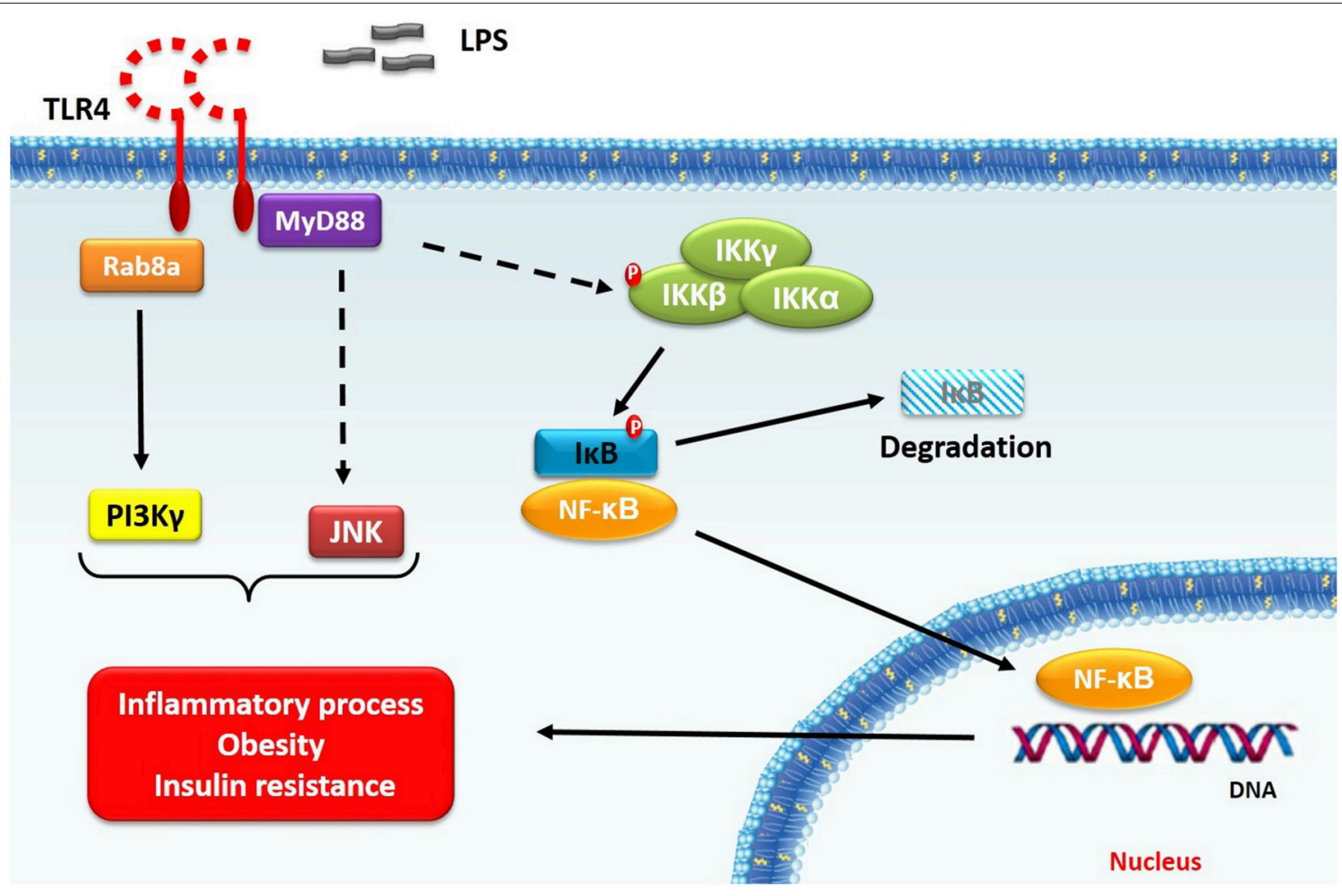

FIGURE 1 | TLR4 signaling in obesity. TLR4 activation (i.e., after LPS stimulus) leads to signal transduction, which involves IKK- $\beta-N F-\kappa B$ classical pathway. After stimulation, MyD88 is recruited to TLR4 receptor to mediate downstream signaling, including IKK- $\beta$ phosphorylation. Once activated, IKK- $\beta$ phosphorylates I $B$ protein, which, in turn, release NF-кB complex. Besides this pathway, TLR4 signaling also results in PI3K $\gamma$ and JNK activation. Taken together, these signaling proteins play a fundamental role in inflammation, obesity and insulin resistance relationship. Note: dashed arrows indicate that other signaling intermediates are required. 


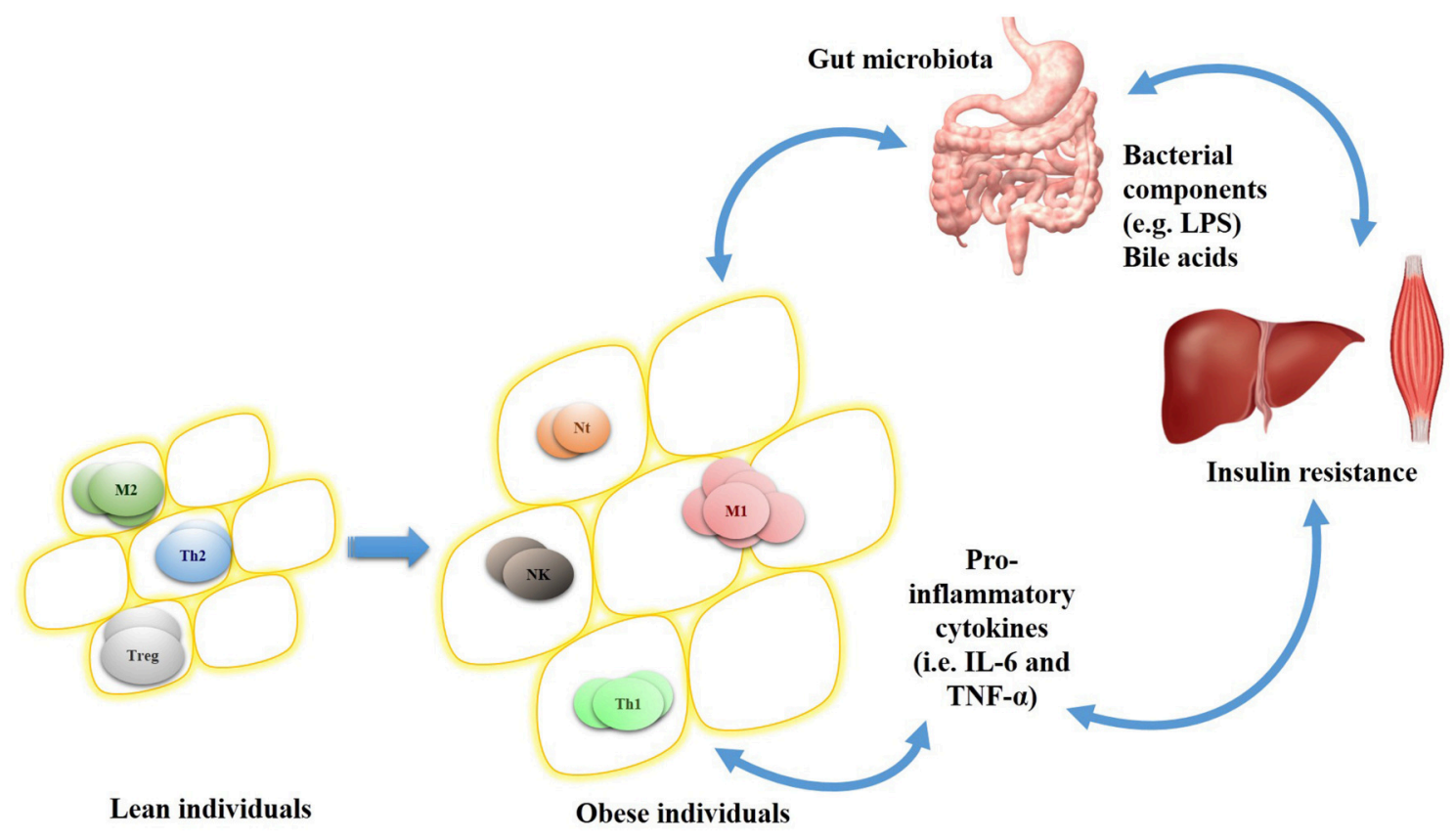

FIGURE 2 | Adipocytes-infiltrating immune cell profile in lean and obese individuals and relationship between gut microbiota, insulin sensitive organs, and inflammation. In lean individuals, adipocytes cells (yellow circles) are infiltrated by anti-inflammatory cells (e.g., M2 macrophage and regulatory T cell [Treg]) and helper T lymphocyte 2 (Th2). On the other hand, obese individuals have hypertrophied adipocytes associated with pro-inflammatory cells (e.g., M1 macrophage and neutrophils [Nt]), NK and Th1 lymphocyte, which altogether induces pro-inflammatory mediators release. This inflammatory cell infiltration is influenced by the cytokines produced locally and also by host-gut microbiota interactions (e.g., bile acids and LPS influence), which in turn are directly associated to obesity and its complications (i.e., insulin resistance).

Obesity leads to an increase in IKK- $\beta-\mathrm{NF}-\mathrm{\kappa B}$ signaling, a primary regulator of inflammatory response, in the liver. This phenomenon is related to fatty liver accumulation, which activates IKK- $\beta-\mathrm{NF}-\mathrm{\kappa} B$, resulting in pro-inflammatory cytokines and insulin resistance (Cai et al., 2005). In addition, myeloid cells IKK- $\beta$ absence improves systemic insulin sensitivity (Arkan et al., 2005). Hypothalamic neurons IKK- $\beta-N F-\kappa B$ axis is also involved in obesity and insulin resistance (Zhang et al., 2008). This pathway is a target to non-acetylated salicylates drugs, which can emerge as a new treatment to glucose reduction in diabetic patients (Rumore and Kim, 2010). Furthermore, the IKKE deficiency protects from obesity, inflammation and insulin resistance (Chiang et al., 2009; Olefsky, 2009).

Other signaling protein is related to obesity (Hirosumi et al., 2002) and insulin resistance is cJun NH2-terminal kinase (JNK; Nguyen et al., 2005), a stress-responsive MAPK. Han et al. (2013) demonstrated that high-fat diet fed mice with JNK-deficient macrophages remains insulin-sensitive. However, these animals still develop obesity. On the other hand, Solinas et al. (2007) showed that JNK absence in non-hematopoietic cells reduces fat gain, possibly by increasing metabolic rate, besides insulin sensitivity improvement. JNK is also important to obesity induced-inflammation, since its deletion reduces M1 macrophage polarization, adipose tissue infiltration by macrophages and inflammatory cytokines levels (Solinas et al., 2007; Han et al., 2013). Between these cytokines, IL-6 is implicated to insulin resistance. Perry et al. (2015) demonstrated that macrophage IL-6 production via JNK pathway promotes lipolysis in white adipose tissue, which in turn are related to hepatic glucose increase production. Besides JNK peripheral role in obesity, studies provide evidences that JNK deficiency in the central nervous system, mostly of hypothalamic-pituitary axis, improves insulin sensitivity and reduces body mass (Belgardt et al., 2010; Sabio et al., 2010).

Between signaling proteins involved in inflammation and obesity, PI3K has emerged as an obesity treatment target (Wymann and Solinas, 2013; Perino et al., 2014). This class of enzymes catalyze the phosphorylation of inositol phospholipids to generate molecular messengers (Hawkins and Stephens, 2015). $\mathrm{PI} 3 \mathrm{~K} \beta$ and PI3K $\gamma$ isoforms inhibition are implicated in fat mass reduction by promoting increased energy expenditure in mice (Perino et al., 2014). Additionally, blockade of PI3K $\gamma$ reduces pro-inflammatory macrophages infiltration into adipose tissue (Kobayashi et al., 2011). In fact, different receptors stimulation (e.g., $\mathrm{G}$ protein-coupled or tyrosine kinases receptors) induces PI $3 \mathrm{~K} \gamma$ activation, which promotes integrin $\alpha 4 \beta 1$ activation in myeloid cells, a fundamental step in cell migration (Schmid et al., 2011).

Furthermore, PI $3 \mathrm{~K} \gamma$ inhibition is also related to ameliorate obesity complications, mostly improving systemic insulin sensitivity (Becattini et al., 2011; Kobayashi et al., 2011). In this regard, TLR4/PI3K $\gamma$ axis is important not only for immune cells, but also for non-immune cells. Hepatocytes TLR4 absence, but 
not in myeloid cells, improved glucose tolerance and enhanced insulin sensitivity. Besides that, it also attenuates inflammatory response (Jia et al., 2014). Becattini et al. (2011) showed that PI3K $\gamma$ activity within non-hematopoietic cells promotes insulin resistance in high-fat diet fed mice. However, the relationship between TLR4 and cell signaling proteins (summarized in Figure 1), obesity and metabolic syndrome is not completely established.

\section{CONCLUSIONS AND PERSPECTIVES}

Although several pathophysiological studies of metabolic syndrome and obesity were reported, little has been done about translational research in this field. In this regard, gut microbiota

\section{REFERENCES}

Aderem, A., and Ulevitch, R. J. (2000). Toll-like receptors in the induction of the innate immune response. Nature 406, 782-787. doi: 10.1038/35021228

Akira, S., Uematsu, S., and Takeuchi, O. (2006). Pathogen recognition and innate immunity. Cell 124, 783-801. doi: 10.1016/j.cell.2006.02.015

Alexopoulou, L., Holt, A. C., Medzhitov, R., and Flavell, R. A. (2001). Recognition of double-stranded RNA and activation of NF- $\kappa \mathrm{B}$ by toll-like receptor 3. Nature 413, 732-738. doi:10.1038/35099560

Amano, S. U., Cohen, J. L., Vangala, P., Tencerova, M., Nicoloro, S. M., Yawe, J. C., et al. (2014). Local proliferation of macrophages contributes to obesity-associated adipose tissue inflammation. Cell Metab. 19, 162-172. doi: 10.1016/j.cmet.2013.11.017

Andreasen, A. S., Larsen, N., Pedersen-Skovsgaard, T., Berg, R. M., Møller, K., Svendsen, K. D., et al. (2010). Effects of Lactobacillus acidophilus NCFM on insulin sensitivity and the systemic inflammatory response in human subjects. Br. J. Nutr. 104, 1831-1838. doi: 10.1017/S0007114510002874

Arkan, M. C., Hevener, A. L., Greten, F. R., Maeda, S., Li, Z. W., Long, J. M., et al. (2005). IKK-beta links inflammation to obesity-induced insulin resistance. Nat Med. 11, 191-198. doi: 10/nm1185

Aronsson, L., Huang, Y., Parini, P., Korach-André, M., Håkansson, J., Gustafsso, J., et al. (2010). Decreased fat storage by Lactobacillus paracasei is associated with increased levels of angiopoietin-like 4 protein (ANGPTL4). PLoS ONE 5:e13087. doi: 10.1371/journal.pone.0013087

Ashley, N. T., Weil, Z. M., and Nelson, R. J. (2012). Inflammation: mechanisms, costs, and natural variation. Annu. Rev. Ecol. Evol. Syst. 43, 385-406. doi: 10.1146/annurev-ecolsys-040212-092530

Bäckhed, F., Ding, H., Wang, T., Hooper, L. V., Koh, G. Y., Nagy, A., et al. (2004). The gut microbiota as an environmental factor that regulates fat storage. Proc. Natl. Acad. Sci. U.S.A. 101, 15718-15723. doi: 10.1073/pnas.04070 76101

Bäckhed, F., Ley, R. E., Sonnenburg, J. L., Peterson, D. A., and Gordon, J. I. (2005). Host-bacterial mutualism in the human intestine. Science. 307, 1915-1920. doi :10.1126/science. 1104816

Bäckhed, F., Manchester, J. K., Semenkovich, C. F., and Gordon, J. I. (2007). Mechanisms underlying the resistance to diet-induced obesity in germ-free mice. Proc. Natl. Acad. Sci. U.S.A. 104, 979-984. doi: 10.1073/pnas.0605374104

Bailey, M., Haverson, K., Inman, C., Harris, C., Jones, P., Corfield, G., et al. (2005). The development of the mucosal immune system pre- and post-weaning: balancing regulatory and effector function. Proc. Nutr. Soc. 64, 451-457. doi: 10.1079/PNS2005452

Bassi, G. S., Brognara, F., Castania, J. A., Talbot, J., Cunha, T. M., Cunha, F. Q., et al. (2015). Baroreflex activation in conscious rats modulates the joint inflammatory response via sympathetic function. Brain Behav. Immun. 49, 140-147. doi: 10.1016/j.bbi.2015.05.002

Becattini, B., Marone, R., Zani, F., Arsenijevic, D., Seydoux, J., Montani, J. P., et al. (2011). PI3K $\gamma$ within a nonhematopoietic cell type negatively regulates dietinduced thermogenesis and promotes obesity and insulin resistance. Proc. Natl. Acad. Sci. U.S.A. 108, E854-E863. doi: 10.1073/pnas.1106698108 emerges with a key role in these disorders by interacting with host metabolism (i.e., bile acid biotransformation) or by promoting immune responses (i.e., TLR activation and cytokines production). Hence, gut microbiota-driven inflammation may promote the activation of the signal transducers IKK $\beta$, $\mathrm{JNK}$, and $\mathrm{PI} 3 \mathrm{~K} \gamma$ which in turn control obesity development, adipose tissue inflammation and insulin resistance. Further studies may consider the relationship between gut microbiota, immune system and obesity (Figure 2) as a novel scope for disorders prevention and health maintenance. This comprehension will allow the development of new specific targets and integrated strategies to modulate gut microbiota in order to improve or even treat metabolic syndrome and obesity.

Belgardt, B. F., Mauer, J., Wunderlich, F. T., Ernst, M. B., Pal, M., Spohn, G., et al. (2010). Hypothalamic and pituitary c-Jun N-terminal kinase 1 signaling coordinately regulates glucose metabolism. Proc. Natl. Acad. Sci. U.S.A. 107, 6028-6033. doi: 10.1073/pnas.1001796107

Belkaid, Y., and Hand, T. (2014). Role of the microbiota in immunity and inflammation. Cell. 157, 1-42. doi: 10.1016/j.cell.2014.03.011

Bès-Houtmann, S., Roche, R., Hoareau, L., Gonthier, M. P., Festy, F., Caillens, H., et al. 2007. Presence of functional TLR2 and TLR4 on human adipocytes. Histochem. Cell Biol. 127, 131-137. doi: 10.1007/s00418-006-0230-1

Beutler, B. (2003). Innate immune responses to microbial poisons: discovery and function of the toll-Like receptors. Annu. Rev. Pharmacol. Toxicol. 43, 609-628. doi: 10.1146/annurev.pharmtox.43.100901.135729

Bolus, W. R., Gutierrez, D. A., Kennedy, A. J., Anderson-Baucum, E. K., and Hasty, A. H. (2015). CCR2 deficiency leads to increased eosinophils, alternative macrophage activation, and type 2 cytokine expression in adipose tissue. J. Leukoc. Biol. 98, 1-11. doi: 10.1189/jlb.3HI0115-018R

Brestoff, J. R., Kim, B. S., Saenz, S. A., Stine, R. R., and Monticelli, L. A., Sonnenberg, G. F., et al. (2014). Group 2 innate lymphoid cells promote beiging of white adipose tissue and limit obesity. Nature 519, 242-246. doi: 10.1038 /nature 14115

Burdette, A. M., and Hillb, T. D. (2008). An examination of processes linking perceived neighborhood disorder and obesity. Soc. Sci. Med. 67, 38-46. doi: 10.1016/j.socscimed.2008.03.029

Cai, D., Yuan, M., Frantz, D. F., Melendez, P. A., Hansen, L., Lee, J., et al. (2005). Local and systemic insulin resistance resulting from hepatic activation of IKK-beta and NF-kappaB. Nat. Med. 11, 183-190. doi: 10.1038/nm1166

Cani, P. D., and Delzenne, N. M. (2009). The role of the gut microbiota in energy metabolism and metabolic disease. Curr. Pharm. Des. 15, 1546-1558. doi: 10.2174/138161209788168164

Cani, P. D., Bibiloni, R., Knauf, C., Waget, A., Neyrinck, A. M., Delzenne, N. M., et al. (2008). Changes in gut microbiota control metabolic endotoxemiainduced inflammation in high-fat diet-induced obesity and diabetes in mice. Diabetes 57, 1470-1481. doi: 10.2337/db07-1403

Cariou, B., van Harmelen, K., Duran-Sandoval, D., van Dijk, T. H., Grefhorst, A., Abdelkarim, M., et al. (2006). The farnesoid X receptor modulates adiposity and peripheral insulin sensitivity in mice. J. Biol. Chem. 281, 11039-11049. doi: 10.1074/jbc.M510258200

Chiang, S. H., Bazuine, M., Lumeng, C. N., Geletka, L. M., Mowers, J., White, N. M., et al. 2009. The protein kinase IKKepsilon regulates energy balance in obese mice. Cell. 138, 961-975. doi: 10.1016/j.cell.2009.06.046

Cho, K. W., Morris, D. L., DelProposto, J. L., Geletka, L., Zamarron, B., and Martinez-Santibanez, G. (2014). An MHC II-dependent activation loop between adipose tissue macrophages and CD4+ T cells controls obesityinduced inflammation. Cell Rep. 9, 605-617. doi: 10.1016/j.celrep.2014. 09.004

Cinti, S., Mitchell, G., Barbatelli, G., Murano, I., Ceresi, E., Faloia, E., et al. 2005. Adipocyte death defines macrophage localization and function in adipose tissue of obese mice and humans. J Lipid Res. 46, 2347-2355. doi: 10.1194/jlr.M500294-JLR200 
Clarke, S. F., Murphy, E. F., Nilaweera, K., Ross, P. R., Shanahan, F., O’Toole, P. W., et al. (2012). The gut microbiota and its relationship to diet and obesity. Gut Microbes. 3, 186-202. doi: 10.4161/gmic.20168

Cotillard, A., Kennedy, S. P., Kong, L. C., Prifti, E., Pons, N., Chatelier, E. L., et al. (2013). Dietary intervention impact on gut microbial gene richness. Nature 500, 585-588. doi: 10.1038/nature 12480

Dalmas, E., Clément, K., and Guerre-Millo, M. (2011). Defining macrophage phenotype and function in adipose tissue. Trends Immunol. 32, 307-314. doi: 10.1016/j.it.2011.04.008

Dasu, M. R., and Jialal, I. (2010). Free fatty acids in the presence of high glucose amplify monocyte inflammation via toll-like receptors. Am. J. Physiol. Endocrinol. Metab. 300, E145-E154. doi: 10.1152/ajpendo.00490.2010

David, L. A., Maurice, C. F., Carmody, R. N., Gootenberg, D. B., Button, J. E., Wolfe, B. E., et al. (2014). Diet rapidly and reproducibly alters the human gut microbiome. Nature 505, 559-563. doi: 10.1038/nature 12820

Davis, J. E., Braucher, D. R., Walker-Daniels, J., and Spurlock, M. E. (2011). Absence of Tlr2 protects against high-fat diet-induced inflammation and results in greater insulin-stimulated glucose transport in cultured adipocytes. J. Nutr. Biochem. 22, 136-141. doi: 10.1016/j.jnutbio.2009.12.008

Davis, J. E., Gabler, N. K., Walker-Daniels, J., and Spurlock, M. E. (2008). Tlr-4 deficiency selectively protects against obesity induced by diets high in saturated fat. Obesity (Silver Spring) 16, 1248-1255. doi: 10.1038/oby.2008.210

de Mello, V. D., Kolehmainen, M., Pulkkinen, L., Schwab, U., Mager, U., Laaksonen, D. E., et al. (2008). Downregulation of genes involved in NFkappaB activation in peripheral blood mononuclear cells after weight loss is associated with the improvement of insulin sensitivity in individuals with the metabolic syndrome: the GENOBIN study. Diabetologia 51, 2060-2067. doi: 10.1007/s00125-008-1132-7

de Theije, C. G., Wopereis, H., Ramadan, M., van Eijndthoven, T., Lambert, J., Knol, J., et al. (2014). Altered gut microbiota and activity in a murine model of autism spectrum disorders. Brain Behav. Immun. 37, 197-206. doi: 10.1016/j.bbi.2013.12.005

de Vasconcelos, D. I. B., Leite, J. A., Carneiro, L. T., Piuvezam, M. R., Lima, M. R. V., de Morais, L. C. L., et al. (2011). Anti-inflammatory and antinociceptive activity of ouabain in mice. Mediators Inflamm. 2011, 1-11. doi: $10.1155 / 2011 / 912925$

Deban, L., Bottazzi, B., Garlanda, C., de la Torre, Y. M., and Mantovani, A. (2009). Pentraxins: multifunctional proteins at the interface of innate immunity and inflammation. Biofactors 35, 138-145. doi: 10.1002/biof.21

DeMarco, V. G., Aroor, A. R., and Sowers, J. R. (2014). The pathophysiology of hypertension in patients with obesity. Nat. Rev. Endocrinol. 10, 364-376. doi: $10.1038 /$ nrendo.2014.44

Du Clos, T. W. (2013). Pentraxins: structure, function, and role in inflammation. ISRN Inflamm. 2013, 1-22. doi: 10.1155/2013/379040

Elgazar-Carmon, V., Rudich, A., Hadad, N., and Levy, R. (2008). Neutrophils transiently infiltrate intra-abdominal fat early in the course of high-fat feeding. J. Lipid Res. 49, 1894-1903. doi: 10.1194/jlr.M800132-JLR200

Elinav, E., Strowig, T., Kau, A. L., Henao-Mejia, J., Thaiss, C. A., Booth, C. J., et al. (2011). NLRP6 inflammasome regulates colonic microbial ecology and risk for colitis. Cell 145, 745-757. doi: 10.1016/j.cell.2011.04.022

Emanuela, F, Grazia, M., Marco de R., Maria Paola, L., Giorgio, F., Marco, B. (2012). Inflammation as a link between obesity and metabolic syndrome. J. Nutr. Metab. 2012, 1-7. doi: 10.1155/2012/476380

Ferrante, A. W.Jr. (2013). The immune cells in adipose tissue. Diabetes Obes. Metab. 3, 34-38. doi: 10.1111/dom.12154

Fresno, M., Alvarez, R., and Cuesta, N. (2011). Toll-like receptors, inflammation, metabolism and obesity. Arch. Physiol. Biochem. 117, 151-164. doi: 10.3109/13813455.2011.562514

Fujimura, E. K., Slusher, N. A., Cabana, M. D., and Lynch, S. V. (2010). Role of the gut microbiota in defining human health. Expert Rev. Anti Infect. Ther. 8, 435-454. doi: 10.1586/eri.10.14

Gregor, M. F., and Hotamisligil, G. S. (2011). Inflammatory mechanisms in obesity. Annu. Rev. Immunol. 29, 415-445. doi: 10.1146/annurev-immunol-031210101322

Guinane, C. M., and Cotter, P. D. (2013). Role of the gut microbiota in health and chronic gastrointestinal disease: understanding a hidden metabolic organ. Ther. Adv. Gastroenterol. 6, 295-308. doi: 10.1177/1756283X13482996

Han, M. S., Jung, D. Y., Morel, C., Lakhani, S. A., Kim, J. K., Flavell, R. A., et al. (2013). JNK expression by macrophages promotes obesity-induced insulin resistance and inflammation. Science 339, 218-222. doi: $10.1126 /$ science. 1227568

Hawkins, P. T., and Stephens, L. R. (2015). PI3K signalling in inflammation. Biochim. Biophys. Acta 1851, 882-897. doi: 10.1016/j.bbalip.2014.12.006

Hayashi, F., Smith, K. D., Ozinsky, A., Hawn, T. R., Eugene, C. Y., Goodlett, D. R., et al. (2001). The innate immune response to bacterial flagellin is mediated bytoll-like receptor 5. Nature 410, 1099-1103. doi: 10.1038/35074106

Hemmi, H., Takeuchi, O., Kawai, T., Kaisho, T., Sato, S., Sanjo, H., et al. (2000). A toll-like receptor recognizes bacterial DNA. Nature 408, 740-745. doi: $10.1038 / 35047123$

Himes, R. W., and Smith, C. W. (2010). Tlr2 is critical for diet-induced metabolic syndrome in a murine model. FASEB J. 24, 731-739. doi: 10.1096/fj.09-141929

Hirosumi, J., Tuncman, G., Chang, L., Görgün, C. Z., Uysal, K. T., Maeda, K., et al. (2002). A central role for JNK in obesity and insulin resistance. Nature 420, 333-336. doi: 10.1038/nature01137

Hirota, S. A., Ng, J., Lueng, A., Khajah, M., Parhar, K., Li, Y., et al. (2011). NLRP3 inflammasome plays a key role in the regulation of intestinal homeostasis. Inflamm. Bowel Dis. 17, 1359-1372. doi: 10.1002/ibd.21478

Hofmann, A. F., and Eckmann, L. (2006). How bile acids confer gut mucosal protection against bacteria. Proc. Natl. Acad. Sci. U.S.A. 103, 4333-4334. doi: $10.1073 /$ pnas.0600780103

Hooper, L. V., Wong, M. H., Thelin, A., Hansson, L., Falk, P. G., and Gordon, J. I., 2001. Molecular analysis of commensal host-microbial relationships in the intestine. Science 291, 881-884. doi: 10.1126/science.291.5505.881

Hooper, V. L., Midtvedt, T., and Gordon, J. I. (2002). How host-microbial interactions shape the nutrient environment of the mammalian intestine. Annu. Rev. Nutr. 22, 283-307. doi: 10.1146/annurev.nutr.22.011602.092259

Hornef, M. W., and Bogdan, C. (2005). The role of epithelial toll-like receptor expression in host defense and microbial tolerance. J Endotoxin Res. 11, 124-128. doi: 10.1179/096805105X35224

Hornung, V., Biller, G. M., Bourquin, C., Ablasser, A., Schlee, M., Uematsu, S., et al. (2005). Sequence-specific potent induction of IFN- $\alpha$ by short interfering RNA in plasmacytoid dendritic cells through TLR7. Nat. Med. 11, 263-270. doi: $10.1038 / \mathrm{nm} 1191$

Hwa, C. H., Bae, Y. C., and Jung, J. S. (2006). Role of toll-like receptors on human adipose-derived stromal cells. Stem Cells 24, 2744-2752. doi: 10.1634/stemcells.2006-0189

Inagaki, T., Moschetta, A., Lee, Y. K., Peng, L., Zhao, G., Downes, M., et al. (2006). Regulation of antibacterial defense in the small intestine by the nuclear bile acid receptor. Proc. Natl. Acad. Sci. U.S.A. 103, 3920-3925. doi: $10.1073 /$ pnas.0509592103

Inouye, K. E., Shi, H., Howard, J. K., Daly, C. H., Lord, G. M., Rollins, B. J., et al. (2007). Absence of CC chemokine ligand 2 does not limit obesity-associated infiltration of macrophages into adipose tissue. Diabetes 56, 2242-2250. doi: $10.2337 / \mathrm{db} 07-0425$

Janeway, C. A., and Medzhitov, R. (2002). Innate immune recognition. Annu. Rev. Immunol. 20, 197-216. doi: 10.1146/annurev.immunol.20.083001.084359

Jauch-Chara, K., and Oltmanns, K. M. (2014). Obesity - a neuropsychological disease? Systematic review and neuropsychological model. Prog. Neurobiol. 114, 84-101. doi: 10.1016/j.pneurobio.2013.12.001

Jia, L., Vianna, C. R., Fukuda, M., Berglund, E. D., Liu, C., Tao, C., et al. (2014). Hepatocyte Toll-like receptor 4 regulates obesity-induced inflammation and insulin resistance. Nat Commun. 5, 1-11. doi: 10.1038/ncomms4878

Kadook, Y., Sato, M., Imaizumi, K., Ogawa, A., Ikuyama, K., Akai, Y., et al. (2010). Regulation of abdominal adiposity by probiotics (Lactobacillus gasseri SBT2055) in adults with obese tendencies in a randomized controlled trial. Eur. J. Clin. Nutr. 64, 636-643. doi: 10.1038/ejen.2010.19

Kanczkowski, W., Ziegler, C. G., Zacharowski, K., and Bornstein, S. R. (2008). Tolllike receptors in endocrine disease and diabetes. Neuroimmunomodulation 15 , 54-60. doi: 10.1159/000135624

Kanda, H., Tateya, S., Tamori, Y., Kotani, K., Hiasa, K., Kitazawa, R., et al. (2006). MCP-1 contributes to macrophage infiltration into adipose tissue, insulin resistance, and hepatic steatosis in obesity. J. Clin. Invest. 116, 1494-1505. doi: $10.1172 /$ JCI26498

Kawai, T., and Akira, S. (2010). The role of pattern-recognition receptors in innate immunity: update on toll-like receptors. Nat. Immunol. 11, 373-384. doi: 10.1038/ni.1863

Kawasaki, T., and Kawai, T. (2014). Toll-Like receptor signaling pathways. Front. Immunol. 5:461. doi: 10.3389/fimmu.2014.00461 
Kelly, D., Campbell, J. I., King, T. P., Grant, G., Jansson, E. A., Coutts, A. G. P., et al. (2004). Commensal anaerobic gut bacteria attenuate inflammation by regulating nuclear-cytoplasmic shuttling of PPAR- $\gamma$ and RelA. Nat. Immunol. 5, 104-112. doi: 10.1038/ni1018

Keophiphath, M., Rouault, C., Divoux, A., Clément, K., and Lacasa, D. (2010). CCL5 promotes macrophage recruitment and survival in human adipose tissue. Arterioscler. Thromb. Vasc. Biol. 30, 39-45. doi: 10.1161/ATVBAHA.109.197442.

Khan, S. A., Ali, A., Khan, S. A., Zahran, S. A., Damanhouri, G., Azhar, E., et al. (2014). Unraveling the complex relationship triad between lipids, obesity, and inflammation. Mediators Inflamm. 2014, 1-16. doi: 10.1155/2014/502749

Kim, D., Kim, J., Yoon, J. H., Ghim, J., Yea, K., Song, P., et al. (2014). CXCL12 secreted from adipose tissue recruits macrophages and induces insulin resistance in mice. Diabetologia 57, 1456-1465. doi: 10.1007/s00125-0143237-5

Kim, K. A., Gu, W., Lee, I. A., Joh, E. H., and Kim, D. H., (2012). High fat diet-induced gut microbiota exacerbates inflammation and obesity in mice via the TLR4 signaling pathway. PLoS ONE 7:e47713. doi: 10.1371/journal.pone.0047713

Kim, K. Y., Jeong, H. J., and Kim, H. M. (2013). The role of T-bet in obesity: lack of T-bet causes obesity in male mice. J. Nutr. Biochem. 24, 240-247. doi: 10.1016/j.jnutbio.2012.05.010

Kirk, E. A., Sagawa, Z. K., McDonald, T. O., O’Brien, K. D., and Heinecke, J. W. (2008). Monocyte chemoattractant protein deficiency fails to restrain macrophage infiltration into adipose tissue. Diabetes 57, 1254-1261. doi: $10.2337 / \mathrm{db} 07-1061$

Kitade, H., Sawamoto, K., Nagashimada, M., Inoue, H., Yamamoto, Y., Sai, Y., et al. (2012). CCR5 plays a critical role in obesity-induced adipose tissue inflammation and insulin resistance by regulating both macrophage recruitment and M1/M2 status. Diabetes 61, 1680-1690. doi: 10.2337/db111506.

Kobayashi, N., Ueki, K., Okazaki, Y., Iwane, A., Kubota, N., Ohsugi, M., et al. (2011). Blockade of class IB phosphoinositide-3 kinase ameliorates obesityinduced inflammation and insulin resistance. Proc. Natl. Acad. Sci. U.S.A. 108, 5753-5758. doi: 10.1073/pnas.1016430108

Kraakman, M. J., Kammoun, H. L., Allen, T. L., Deswaerte, V., Henstridge, D. C., Estevez, E., et al. (2015). Blocking IL-6 trans-signaling prevents high-fat dietinduced adipose tissue macrophage recruitment but does not improve insulin resistance. Cell Metab. 21, 403-416. doi: 10.1016/j.cmet.2015.02.006

Kraakman, M. J., Murphy, A. J., Jandeleit-Dahm, K., and Kammoun, H. L. (2014). Macrophage polarization in obesity and type 2 diabetes: weighing down our understanding of macrophage function? Front. Immunol. 5:470. doi: 10.3389/fimmu.2014.00470

Krinninger, P., Ensenauer, R., Ehlers, K., Rauh, K., Stoll, J., Krauss-Etschmann, S., et al. (2014). Peripheral monocytes of obese women display increased chemokine receptor expression and migration capacity. J. Clin. Endocrinol. Metab. 99, 2500-2509. doi: 10.1210/jc.2013-2611

Latz, E., Xiao, T. S., and Stutz, A. (2013). Activation and regulation of the inflammasomes. Nat. Rev. Immunol. 13, 397-411. doi: 10.1038/nri3452

Lee, C. C., Avalos, A. M., and Ploegh, H. L. (2012). Accessory molecules for toll-like receptors and their function. Nat. Rev. Immunol. 12, 168-179. doi: 10.1038/nri3151

Lee, J. Y., Sohn, K. H., Rhee, S. H., and Hwang, D. (2001). Saturated fatty acids, but not unsaturated fatty acids, induce the expression of cyclooxygenase-2 mediated through toll-like receptor 4. J. Biol. Chem. 276, 16683-16689. doi: 10.1074/jbc.M011695200

Lee, J. Y., Ye, J., Gao, Z., Youn, H. S., Lee, W. H., Zhao, L., et al. (2003). Reciprocal modulation of toll-like receptor-4 signaling pathways involving MyD88 and phosphatidylinositol 3-kinase/AKT by saturated and polyunsaturated fatty acids. J. Biol. Chem. 278, 37041-37051. doi: 10.1074/jbc.M3052 13200.

Leite, J. A., Alves, A. K. A., Galvão, J. G. M., Teixeira, M. P., Cavalcante-Silva, L. H. A., Scavone, C., et al. (2015). Ouabain modulates zymosan-induced peritonitis in mice. Mediators Inflamm. 2015, 1-12. doi: 10.1155/2015/265798

Lemaitre, B., Nicolas, E., Michaut, L., Reichhart, J. M., and Hoffmann, J. A. (1996). The dorsoventral regulatory gene cassette spatzle/Toll/cactus controls the potent antifungal response in Drosophila adults. Cell 86, 973-983. doi: $10.1016 /$ S0092-8674(00)80172-5
Ley, R. E., Bäckhed, F., Turnbaugh, P., Lozupone, C. A., Knight, R. D., and Gordon, J. I. (2005). Obesity alters gut microbial ecology. Proc. Natl. Acad. Sci. U.S.A. 102, 11070-11075. doi: 10.1073/pnas.0504978102

Liu, K., Zhao, E., Ilyas, G., Lalazar, G., Lin, Y., Haseeb, M., et al. (2015). Impaired macrophage autophagy increases the immune response in obese mice by promoting proinflammatory macrophage polarization. Autophagy 11, 271-284. doi: 10.1080/15548627.2015.1009787

Lotz, M., Gütle, D., Walther, S., Ménard, S., Bogdan, C., and Hornef, M. W. (2003). Postnatal acquisition of endotoxin tolerance in intestinal epithelial cells. J. Exp. Med. 203, 973-984. doi: 10.1084/jem.20050625

Luckheeram, R. V., Zhou, R., Verma, A. D., and Xia, B. (2012). CD4? T cells: differentiation and functions. Clin. Dev. Immunol. 2012, 1-12. doi: $10.1155 / 2012 / 925135$

Luo, L., Wall, A. A., Yeo, J. C., Condon, N. D., Norwood, S. J., Schoenwaelder, S., et al. (2014). Rab8a interacts directly with PI3K $\gamma$ to modulate TLR4-driven PI3K and mTOR signalling. Nat. Commun. 15, 1-13. doi: 10.1038/ncomms5407

Lynch, L., Michelet, X., Zhang, S., Brennan, P. J., Moseman, A., Lester, C., et al. (2015). Regulatory iNKT cells lack expression of the transcription factor PLZF and control the homeostasis of T(reg) cells and macrophages in adipose tissue. Nat. Immunol. 16, 85-95. doi: 10.1038/ni.3047

Ma, K., Saha, P. K., Chan, L., and Moore, D. D. (2006). Farnesoid X receptor is essential for normal glucose homeostasis. J. Clin. Invest. 116, 1102-1109. doi: 10.1172/JCI25604.

Ma, Y., Gao, M., Sun, H., and Liu, D. (2015). Interleukin-6 gene transfer reverses body weight gain and fatty liver in obese mice. Biochim. Biophys. Acta 1852, 1001-1011. doi: 10.1016/j.bbadis.2015.01.017

Martelli, D., McKinley, M. J., and McAllen, R. M. (2014). The cholinergic antiinflammatory pathway: a critical review. Auton. Neurosci. 182, 65-69. doi: 10.1016/j.autneu.2013.12.007

Martin, R., Nauta, A. J., Amor, K. B., Knippels, L. M. J., Knol, J., and Garssen, J. (2010). Early life: gut microbiota and immune development in infancy. Benef. Microbes 1, 367-382. doi: 10.3920/BM2010.0027

Mauer, J., Chaurasia, B., Goldau, J., Vogt, M. C., Ruud, J., Nguyen, K. D., et al. (2014). Signaling by IL-6 promotes alternative activation of macrophages to limit endotoxemia and obesity associated resistance to insulin. Nat. Immunol. 15, 423-430. doi: 10.1038/ni.2865

McGill, A. (2014). Causes of metabolic syndrome and obesity-related comorbidities part 1: a composite unifying theory review of human-specific coadaptations to brain energy consumption. Arch. Public Health 72, 1-13. doi: 10.1186/2049-3258-72-30

McLaughlin, T., Liu, L. F., Lamendola, C., Shen, L., Morton, J., Rivas, H., et al. (2014). T-cell profile in adipose tissue is associated with insulin resistance and systemic inflammation in humans. Arterioscler. Thromb. Vasc. Biol. 34, 2637-2643. doi: 10.1161/ATVBAHA.114.304636.

Medzhitov, R. (2008). Origin and physiological roles of inflammation. Nature 454, 428-435. doi: 10.1038/nature07201

Medzhitov, R. (2010). Inflammation 2010: new adventures of an old flame. Cell 140, 771-776. doi: 10.1016/j.cell.2010.03.006

Medzhitov, R., Preston-Hurlburt, P., and Janeway, C. A. Jr. (1997). A human homologue of the Drosophila Toll protein signals activation of adaptive immunity. Nature 388, 394-397.

Medzhitov, R. (2007). Recognition of microorganisms and activation of the immune response. Nature 449, 819-826. doi: 10.1038/nature06246

Merritt, M. E., and Donaldson, J. R. (2009). Effect of bile salts on the DNA and membrane integrity of enteric bacteria. J. Med. Microbiol. 58, 1533-1541. doi: 10.1099/jmm.0.014092-0.

Milanski, M., Degasperi, G., Coope, A., Morari, J., Denis, R., Cintra, D. E., et al. (2009). Saturated fatty acids produce an inflammatory response predominantly through the activation of TLR4 signaling in hypothalamus: implications for the pathogenesis of obesity. J. Neurosci. 29, 359-370. doi: 10.1523/JNEUROSCI.2760-08.2009

Mirhafez, S. R., Mohebati, M., Disfani, M. F., Karimian, M. S., Ebrahimi, M., Avan, A., et al. (2014). An imbalance in serum concentrations of inflammatory and anti-inflammatory cytokines in hypertension. J. Am. Soc. Hypertens. 8, 614-623. doi: 10.1016/j.jash.2014.05.007

Mitchell, S., and Shaw, D. (2015). The worldwide epidemic of female obesity. Best Pract. Res. Clin. Obstet. Gynaecol. 29, 289-299. doi: 10.1016/j.bpobgyn.2014.10.002 
Miyoshi, M., Ogawa, A., Higurashi, S., and Kadooka, Y. (2014). Anti-obesity effect of Lactobacillus gasseri SBT2055 accompanied by inhibition of proinflammatory gene expression in the visceral adipose tissue in diet-induced obese mice. Eur. J. Nutr. 53, 599-606. doi: 10.1007/s00394-013-0568-9

Nara, N., Nakayama, Y., Okamoto, S., Tamura, H., Kiyono, M., Muraoka, M., et al. (2007). Disruption of CXC motif chemokine ligand-14 in mice ameliorates obesity-induced insulin resistance. J. Biol. Chem. 282, 30794-30803. doi: 10.1074/jbc.M700412200

Nguyen, M. T., Satoh, H., Favelyukis, S., Babendure, J. L., Imamura, T., Sbodio, J. I., et al. (2005). JNK and tumor necrosis factor-alpha mediate free fatty acid-induced insulin resistance in 3T3-L1 adipocytes. J. Biol. Chem. 280, 35361-35371. doi: 10.1074/jbc.M504611200.

Nordlander, S., Pott, J., and Maloy, K. J. (2014). NLRC4 expression in intestinal epithelial cells mediates protection against an enteric pathogen. Mucosal Immunol. 7, 775-785. doi: 10.1038/mi.2013.95.

Olefsky, J. M. (2009). IKKepsilon: a bridge between obesity and inflammation. Cell 138, 834-836. doi: 10.1016/j.cell.2009.08.018

Orr, J. S., Puglisi, M. J., Ellacott, K. L., Lumeng, C. N., Wasserman, D. H., and Hasty, A. H. (2012). Toll-like receptor 4 deficiency promotes the alternative activation of adipose tissue macrophages. Diabetes 61, 2718-2727. doi: 10.2337/db11-1595

Park, D. Y., Ahn, Y. T., Park, S. H., Huh, C. S., Yoo, S. R., Yu, R., et al. (2013). Supplementation of Lactobacillus curvatus HY7601 and Lactobacillus plantarum KY1032 in diet-induced obese mice is associated with gut microbial changes and reduction in obesity. PLoS ONE 8:e59470. doi: 10.1371/journal.pone.0059470

Pekkala, S., Munukka, E., Kong, L., Pöllänen, E., Autio, R., Roos, C., et al. (2015). Toll-like receptor 5 in obesity: the role of gut microbiota and adipose tissue inflammation. Obesity 23, 581-590. doi: 10.1002/oby.20993

Perino, A., Beretta, M., Kiliæ, A., Ghigo, A., Carnevale, D., Repetto, I. E., et al. (2014). Combined inhibition of PI3K $\beta$ and PI3K $\gamma$ reduces fat mass by enhancing $\alpha-\mathrm{MSH}$-dependent sympathetic drive. Sci. Signal. 18, 1-12. doi: 10.1126/scisignal.2005485

Perry, R. J., Camporez, J. P., Kursawe, R., Titchenell, P. M., Zhang, D., Perry, C. J., et al. (2015). Hepatic acetyl CoA links adipose tissue inflammation to hepatic insulin resistance and type 2 diabetes. Cell 160, 745-758. doi: 10.1016/j.cell.2015.01.012

Pietsch, J., Batra, A., Stroh, T., Fedke, I., Glauben, R., Okur, B., et al. (2006). Tolllike receptor expression and response to specific stimulation in adipocytes and preadipocytes: on the role of fat in inflammation. Ann. N.Y. Acad. Sci. 1072, 407-409. doi: 10.1196/annals.1326.021

Poitou, C., Dalmas, E., Renovato, M., Benhamo, V., Hajduch, F., Abdennour, M., et al. (2011). CD $14^{d i m} \mathrm{CD} 16^{+}$and $\mathrm{CD} 14^{+} \mathrm{CD} 16^{+}$monocytes in obesity and during weight loss: relationships with fat mass and subclinical atherosclerosis. Arterioscler. Thromb. Vasc. Biol. 31, 2322-2330. doi: 10.1161/ATVBAHA.111.230979

Poltorak, A., He, X., Smirnova, I., Liu, M. Y., Van HHuffel, C., Du, X., et al. (1998a). Defective LPS signaling in $\mathrm{C} 3 \mathrm{H} / \mathrm{HeJ}$ and $\mathrm{C} 57 \mathrm{BL} / 10 \mathrm{ScCr}$ mice: mutations in Tlr4 gene. Science 282, 2085-2088. doi: 10.1126/science.282.5396.2085

Poltorak, A., Smirnova, I., He, X., Liu, M. Y., Van Huffel, C., Birdwell, D., et al. (1998b). Genetic and physical mapping of the LpsLocus: identification of the Toll-4 receptor as a candidate gene in the critical region. Blood Cells Mol. Dis. 24, 340-355. doi: 10.1006/bcmd.1998.0201

Pott, J., and Hornef, M. (2012). Innate immune signalling at the intestinal epithelium in homeostasis and disease. EMBO Rep. 13, 684-698. doi: 10.1038/embor.2012.96

Poulain-Godefroy, O., and Froguel, P. (2007). Preadipocyte response and impairment of differentiation in an inflammatory environment. Biochem. Biophys. Res. Commun. 356, 662-667. doi: 10.1016/j.bbrc.2007.03.053

Prawitt, J., Abdelkarim, M., Stroeve, J. H., Popescu, I., Duez, H., Velagapudi, V. R., et al. (2011). Farnesoid X receptor deficiency improves glucose homeostasis in mouse models of obesity. Diabetes 60, 1861-1871. doi: 10.2337/db110030

Rabot, S., Membrez, M., Bruneau, A., Gérard, P., Harach, T., Moser, M., et al. (2010). Germ-free C57BL/6J mice are resistant to high-fat-diet-induced insulin resistance and have altered cholesterol metabolism. FASEB J. 24, 4948-4959. doi: 10.1096/fj.10-164921

Raoult, D. (2009). Probiotics and obesity: a link? Nat. Rev. Microbiol. 7, 616. doi: $10.1038 /$ nrmicro2209
Ren, D. L., Sun, A. A., Li, Y. J., Chen, M., Ge, S. C., and Hu, B. (2015). Exogenous melatonin inhibits neutrophil migration through suppression of ERK activation. J. Endocrinol. 227, 49-60. doi: 10.1530/JOE-15-0329

Reyna, S. M., Ghosh, S., Tantiwong, P., Meka, C. S., Eagan, P., Jenkinson, C. P., et al. (2008). Elevated toll-like receptor 4 expression and signaling in muscle from insulin-resistant subjects. Diabetes 57, 2595-2602. doi: 10.2337/db08-0038

Ridlon, J. M., Kang, D. J., and Hylemon, P. B. (2006). Bile salt biotransformations by human intestinal bacteria. J. Lipid Res. 47, 241-259. doi: 10.1194/jlr.R500013-JLR200

Ridlon, J. M., Kang, D. J., Hylemon, P. B., and Bajaj, J. S. (2014). Bile acids and the gut microbiome. Curr. Opin. Gastroenterol. 30, 332-338. doi: 10.1097/MOG.0000000000000057

Rocha, V. Z., Folco, E. J., Sukhova, G., Shimizu, K., Gotsman, I., Vernon, A. H., et al. (2008). Interferon-gamma, a Th1 cytokine, regulates fat inflammation: a role for adaptive immunity in obesity. Circ. Res. 103, 467-476. doi: 10.1161/CIRCRESAHA.108.177105

Rumore, M. M., and Kim, K. S. (2010). Potential role of salicylates in type 2 diabetes. Ann. Pharmacother. 44, 1207-1221. doi: 10.1345/aph.1M483

Sabio, G., Cavanagh-Kyros, J., Barrett, T., Jung, D. Y., Ko, H. J., Ong, H., et al. 2010. Role of the hypothalamic-pituitary-thyroid axis in metabolic regulation by JNK1. Genes Dev. 24, 256-264. doi: 10.1101/gad.1878510.

Sanz, Y., and Moya-Pérez, A. (2014). Microbiota, inflammation and obesity. Adv. Exp. Med. Biol. 817, 291-317. doi: 10.1007/978-1-4939-0897-4_14

Sárvári, A. K., Doan-Xuan, Q. M., Bacsó, Z., Csomós, I., Balajthy, Z., and Fésüs, L. (2015). Interaction of differentiated human adipocytes with macrophages leads to trogocytosis and selective IL-6 secretion. Cell Death Dis. 22, 1-9. doi: 10.1038 /cddis. 2014.579

Schloss, P. D., and Handelsman, J. (2004). Status of the microbial census. Microbiol. Mol. Biol. Rev. 68, 686-691. doi: 10.1128/MMBR.68.4.686-691.2004

Schmid, M. C., Avraamides, C. J., Dippold, H. C., Franco, I., Foubert, P., Ellies, L. G., et al. (2011). Receptor tyrosine kinases and TLR/IL1Rs unexpectedly activate myeloid cell PI $3 \mathrm{k} \gamma$, a single convergent point promoting tumor inflammation and progression. Cancer Cell. 19, 715-727. doi: 10.1016/j.ccr.2011.04.016

Sekirov, I., Russell, S. L., Antunes, L. C., and Finlay, B. B. (2010). Gut microbiota in health and disease. Physiol. Rev. 90, 859-904. doi: 10.1152/physrev.00045.2009

Sell, H., Habich, C., and Eckel, J. (2012). Adaptive immunity in obesity and insulin resistance. Nat. Rev. Endocrinol. 8, 709-716. doi: 10.1038/nrendo.2012.

Sellin, M. E., Maslowski, K. M., Maloy, K. J., and Hardt, W. D. (2015). Inflammasomes of the intestinal epithelium. Trends Immunol. 36, 442-450. doi: 10.1016/j.it.2015.06.002

Sellin, M. E., Müller, A. A., Felmy, B., Dolowschiak, T., Diard, M., Tardivel, A., et al. (2014). Epithelium-intrinsic NAIP/NLRC4 inflammasome drives infected enterocyte expulsion to restrict Salmonella replication in the intestinal mucosa. Cell Host Microbe 16, 237-248. doi: 10.1016/j.chom.2014.07.001

Shaharyar, S., Roberson, L. L., Jamal, O., Younus, A., Blaha, M. J., Ali, S. S., et al. (2015). Obesity and metabolic phenotypes (metabolically healthy and unhealthy variants) are significantly associated with prevalence of elevated Creactive protein and hepatic steatosis in a large healthy Brazilian population. J. Obes. 2015, 1-6. doi: 10.1155/2015/178526

Shi, H., Kokoeva, M. V., Inouye, K., Tzameli, I., Yin, H., and Flier, J. S. (2006). TLR4 links innate immunity and fatty acid-induced insulin resistance. J. Clin. Invest. 116, 3015-3025. doi: 10.1172/JCI28898

Shibolet, O., and Podolsky, D. K. (2007). TLRs in the Gut. IV. Negative regulation of toll-like receptors and intestinal homeostasis: addition by subtraction. Am. J. Physiol. Gastrointest. Liver Physiol. 292, G1469-G1473. doi: 10.1152/ajpgi.00531.2006

Shin, J. H., Shin, D. W., and Noh, M. (2009). Interleukin-17A inhibits adipocyte differentiation in human mesenchymal stem cells and regulates proinflammatory responses in adipocytes. Biochem. Pharmacol. 77, 1835-1844. doi: 10.1016/j.bcp.2009.03.008

Solinas, G., Vilcu, C., Neels, J. G., Bandyopadhyay, G. K., Luo, J. L., Naugler, W., et al. (2007). JNK1 in hematopoietically derived cells contributes to dietinduced inflammation and insulin resistance without affecting obesity. Cell Metab. 6, 386-397. doi: 10.1016/j.cmet.2007.09.011

Štofilová, J., Szabadosová, V., Hrèková, G., Salaj, R., and Bertková, I., Hijová, E. (2015). Co-administration of a probiotic strain Lactobacillus plantarum LS/07 CCM7766 with prebiotic inulin alleviates the intestinal inflammation in rats 
exposed to N,N-dimethylhydrazine. Int. Immunopharmacol. 24, 361-368. doi: 10.1016/j.intimp.2014.12.022

Strissel, K. J., DeFuria, J., Shaul, M. E., Bennett, G., Greenberg, A. S., and Obin, M. S. (2010). T-cell recruitment and Th1 polarization in adipose tissue during diet-induced obesity in C57BL/6 mice. Obesity (Silver. Spring). 18, 1918-1925. doi: 10.1038/oby.2010.1

Subramanian, V., and Ferrante, A. W.Jr. (2009). Obesity, inflammation, and macrophages. Nestle Nutr. Workshop Ser. Pediatr. Program. 63, 151-159. doi: 10.1159/000209979

Suganami, T., Mieda, T., Itoh, M., Shimoda, Y., Kamei, Y., and Ogawa, Y. (2007). Attenuation of obesity-induced adipose tissue inflammation in $\mathrm{C} 3 \mathrm{H} / \mathrm{HeJ}$ mice carrying a toll-like receptor 4 mutation. Biochem. Biophys. Res. Commun. 354, 45-49. doi: 10.1016/j.bbrc.2006.12.190

Takeda, S., Sato, N., and Morishita, R. (2014). Systemic inflammation, blood-brain barrier vulnerability and cognitive/non-cognitive symptoms in Alzheimer disease: relevance to pathogenesis and therapy. Front. Aging Neurosci. 6:171. doi: 10.3389/fnagi.2014.00171

Takeuchi, O., Hoshino, K., Kawai, T., Sanjo, H., Takada, H., Ogawa, T., et al. (1999). Differential roles of TLR2 and TLR4 in recognition of gram-negative and gram-positive bacterial cell wall components. Immunity 11, 443-451. doi: 10.1016/S1074-7613(00)80119

Talukdar, S., Oh da, Y., Bandyopadhyay, G., Li, D., Xu, J., McNelis, J., et al. (2012). Neutrophils mediate insulin resistance in mice fed a high-fat diet through secreted elastase. Nat. Med. 18, 1407-1412. doi: 10.1038/nm.2885

Thomas, C., Gioiello, A., Noriega, L., Strehle, A., Oury, J., Rizzo, G., et al. (2009). TGR5-mediated bile acid sensing controls glucose homeostasis. Cell Metab. 10, 167-177. doi: 10.1016/j.cmet.2009.08.001

Trayhurn, P. (2005). The biology of obesity. Proc. Nutr. Soc. 64, 31-38. doi: 10.1079/PNS2004406

Tremaroli, V., and Bäckhed, F. (2012). Functional interactions between the gut microbiota and host metabolism. Nature 489, 242-249. doi: 10.1038 /nature 11552

Tsukumo, D. M., Carvalho-Filho, M. A., Carvalheira, J. B., Prada, P. O., Hirabara, S. M., Schenka, A. A., et al. (2007). Loss-of-function mutation in toll-like receptor 4 prevents diet-induced obesity and insulin resistance. Diabetes 56, 1986-1998. doi: 10.2337/db06-1595

Turnbaugh, P. J., Bäckhed, F., Fulton, L., and Gordon, J. I. (2008). Diet-induced obesity is linked to marked but reversible alterations in the mouse distal gut microbiome. Cell Host Microbe 3, 213-223. doi: 10.1016/j.chom.2008.02.015

Turnbaugh, P. J., Hamady, M., Yatsunenko, T., Cantarel, B. L., Duncan, A., Ley, R. E., et al. (2009). A core gut microbiome in obese and lean twins. Nature 457, 480-484. doi: 10.1038/nature07540

Turnbaugh, P. J., Ley, R. E., Mahowald, M. A., Magrini, V., Mardis, E. R., and Gordon, J. I. (2006). An obesity-associated gut microbiome with increased capacity for energy harvest. Nature 444, 1027-1031. doi: 10.1038/nature05414

Ukibe, K., Miyoshi, M., and Kadooka, Y. (2015). Administration of Lactobacillus gasseri SBT2055 suppresses macrophage infiltration into adipose tissue in diet-induced obese mice. Br. J. Nutr. 114, 1180-1187. doi: $10.1017 /$ S0007114515002627

Vael, C., and Desager, K. (2009). The importance of the development of the intestinal microbiota in infancy. Curr. Opin. Pediatr. 21, 794-800. doi: 10.1097/MOP.0b013e328332351b

Vilahur, G., López-Bernal, S., Camino, S., Mendieta, G., Padró, T., and Badimon, L. (2015). Lactobacillus plantarum CECT 7315/7316 intake modulates the acute and chronic innate inflammatory response. Eur. J. Nutr. 54, 1161-1171. doi: 10.1007/s00394-014-0794-9

Vitseva, O. I., Tanriverdi, K., Tchkonia, T. T., Kirkland, J. L., McDonnell, M. E., Apovian, C. M., et al. (2008). Inducible toll-like receptor and NF-kappaB regulatory pathway expression in human adipose tissue. Obesity 16, 932-937. doi: 10.1038/oby.2008.25

Walsh, C. J., Guinane, C. M., O'Toole, P. W., and Cotter, P. D. (2014). Beneficial modulation of the gut microbiota. FEBS Lett. 588, 4120-4130. doi: 10.1016/j.febslet.2014.03.035

Weichhart, T., Costantino, G., Poglitsch, M., Rosner, M., Zeyda, M., Stuhlmeier, K. M., et al. (2008). The TSC-mTOR signaling pathway regulates the innate inflammatory response. Immunity 29, 565-577. doi: 10.1016/j.immuni.2008.08.012
Weisberg, S. P., Hunter, D., Huber, R., Lemieux, J., Slaymaker, S., Vaddi, K., et al. (2006). CCR2 modulates inflammatory and metabolic effects of high-fat feeding. J. Clin. Invest. 116, 115-124. doi: 10.1172/JCI24335.

Wells, J. M., Rossi, O., Meijerink, M., and van Baarlen, P. (2011). Epithelial crosstalk at the microbiota-mucosal interface. Proc. Natl. Acad. Sci. U.S.A. 108, 4607-4614. doi: 10.1073/pnas.1000092107

Wensveen, F. M., Jelenčić, V., Valentić, S., Šestan, M., Wensveen, T. T., Theurich, S., et al. (2015). NK cells link obesity-induced adipose stress to inflammation and insulin resistance. Nat. Immunol. 16, 376-385. doi: 10.1038/ni. 3120

Werling, D., and Jungi, W. T. (2003). Toll- like receptors linking innate and adaptative immune response. Vet. Immunol. Immunopathol. 91, 1-12. doi: 10.1016/S0165-2427(02)00228-3

Williams, M. J., Rodriguez, A., Kimbrell, D. A., and Eldon, E. D. (1997). The 18wheeler mutation reveals complex antibacterial gene regulation in Drosophila host defense. EMBO J. 16, 6120-6130. doi: 10.1093/emboj/16.20.6120

Willing, B. P., Gill, N., and Finlay, B. B. (2010). The role of the immune system in regulating the microbiota. Gut Microbes. 1, 213-223. doi: 10.4161/gmic.1.4.12520

Winer, S., Paltser, G., Chan, Y., Tsui, H., Engleman, E., Winer, D., et al. (2009). Obesity predisposes to Th17 bias. Eur. J. Immunol. 39, 2629-2635. doi: 10.1002/eji.200838893

Wlodarska, M., Thaiss, C. A., Nowarski, R., Henao-Mejia, J., Zhang, J. P., Brown, E M., et al. (2014). NLRP6 inflammasome orchestrates the colonic host-microbial interface by regulating goblet cell mucus secretion. Cell 156, 1045-1059. doi: 10.1016/j.cell.2014.01.026

Wymann, M. P., and Solinas, G. (2013). Inhibition of phosphoinositide 3-kinase $\gamma$ attenuates inflammation, obesity, and cardiovascular risk factors. Ann. N.Y. Acad. Sci. 1280, 44-47. doi: 10.1111/nyas.12037

Xu, X., Su, S., Wang, X., Barnes, V., De Miguel, C., and Ownby, D. (2015). Obesity is associated with more activated neutrophils in African American male youth. Int. J. Obes. (Lond). 39, 26-32. doi: 10.1038/ijo.2014.194

Yadav, H., Lee, J. H., Lloyd, J., Walter, P., and Rane, S. G. (2013). Beneficial metabolic effects of a probiotic via butyrate-induced GLP-1 hormone secretion. J. Biol. Chem. 288, 25088-25097. doi: 10.1074/jbc.M113.452516

Yoo, S. R., Kim, Y. J., Park, D. Y., Jung, U. J., Jeon, S. M., Ahn, Y. T., et al. (2013). Probiotics L. plantarum and L. curvatus in combination alter hepatic lipid metabolism and suppress diet-induced obesity. Obesity (Silver Spring) 21, 2571-2578. doi: 10.1002/oby.20428

Yoshimura, A., Ohnishi, S., Orito, C., Kawahara, Y., Takasaki, H., Takeda, H., et al. (2015). Association of peripheral total and differential leukocyte counts with obesity-related complications in young adults. Obes. Facts 8, 1-16. doi: $10.1159 / 000373881$

Zambetti, L. P., and Mortellaro, A. (2014). NLRPs, microbiota, and gut homeostasis: unravelling the connection. J. Pathol. 233, 321-330. doi: $10.1002 /$ path.4357

Zhang, X., Zhang, G., Zhang, H., Karin, M., Bai, H., and Cai, D. (2008). Hypothalamic IKKbeta/NF-kappaB and ER stress link overnutrition to energy imbalance and obesity. Cell 135, 61-73. doi: 10.1016/j.cell.2008.07.043

Zhao, R., Tang, D., Yi, S., Li, W., Wu, C., and Lu, Y. (2014). Elevated peripheral frequencies of Th22 cells: a novel potent participant in obesity and type 2 diabetes. PLoS ONE 9:e85770. doi: 10.1371/journal.pone.0085770

Ziegler-Heitbrock, L. (2007). The $\mathrm{CD}^{+}{ }^{+} \mathrm{CD} 6^{+}$blood monocytes: their role in infection and inflammation. J. Leukoc. Biol. 81, 584-592. doi: $10.1189 / \mathrm{jlb} .0806510$

Conflict of Interest Statement: The authors declare that the research was conducted in the absence of any commercial or financial relationships that could be construed as a potential conflict of interest.

Copyright (c) 2015 Cavalcante-Silva, Galvão, Silva, Sales-Neto and RodriguesMascarenhas. This is an open-access article distributed under the terms of the Creative Commons Attribution License (CC BY). The use, distribution or reproduction in other forums is permitted, provided the original author(s) or licensor are credited and that the original publication in this journal is cited, in accordance with accepted academic practice. No use, distribution or reproduction is permitted which does not comply with these terms. 